University of Wollongong

Research Online

Faculty of Business - Papers (Archive)

Faculty of Business and Law

2012

Roles and potentials of renewable energy in less-developed economies:

The case of Nepal

Rabindra Nepal

University of Wollongong, rnepal@uow.edu.au

Follow this and additional works at: https://ro.uow.edu.au/buspapers

Part of the Business Commons

Research Online is the open access institutional repository for the University of Wollongong. For further information contact the UOW Library: research-pubs@uow.edu.au 


\title{
Roles and potentials of renewable energy in less-developed economies: The case of Nepal
}

\author{
Abstract \\ Increasing the share of renewable energy in the national energy mix remains one of the major energy \\ policy goals across many economies. This paper assesses the roles and potentials of renewable energy \\ sources in less-developed economies while citing Nepal as an example. Renewable energy has a \\ significant role to play in the electrification of rural areas in developing economies and contribute towards \\ sustainable development. Realizing full potentials of renewable, however, requires addressing both the \\ associated demand-side and supply-side constraints. Innovative subsidies and tax incentives, adequate \\ entrepreneurial support, strengthening institutional arrangement and promoting local community-based \\ organizations such as the cooperatives are the necessary factors in promoting the green technologies in \\ countries like Nepal. International factors such as large scale investment and adequate technology \\ transfer are equally crucial to create a rapid spread and increase affordability of decentralized renewable \\ energy technologies in less-developed economies.

\section{Disciplines \\ Business}

\section{Publication Details} \\ Nepal, R. (2012). Roles and potentials of renewable energy in less-developed economies: The case of \\ Nepal. Renewable and Sustainable Energy Reviews, 16 (4), 2200-2206.
}




\title{
The roles and potentials of renewable energy in less-developed economies
}

\author{
Rabindra Nepal \\ Heriot-Watt University, Department of Economics
}

\begin{abstract}
Increasing the renewable energy share in national energy mix remains one of the major energy policy goals across many economies. This paper assesses the roles and potentials of renewable energy sources in less-developed economies while citing Nepal as an example. Renewable energy has a significant role to play in the electrification of rural areas in developing economies and contribute towards sustainable development. Realizing full potentials of renewable, however, requires addressing both the associated demand-side and supply-side constraints. Innovative subsidies and tax incentives, adequate entrepreneurial support, strengthening institutional arrangement and promoting local community-based organizations such as the cooperatives are the necessary factors in promoting the green technologies in countries like Nepal. International factors such as large scale investment and adequate technology transfer are equally crucial to create a rapid spread and increase affordability of decentralised renewable energy technologies in less-developed economies.
\end{abstract}

Keywords: renewable, electrification, research and development

JEL - Codes: Q42; Q01; O33 


\section{Introduction}

Renewable energy has become an integral aspect of national energy policy goals across many countries post 1973 oil-shock even though the foundations on the economics of exhaustible resources was laid by Hotelling in 1931 (see Hotelling, 1931). Often perceived as a 'backstop technology' $^{1}$ (Dasgupta and Heal, 1973; Heal, 2010), renewable energy sources is increasingly gaining share in the national energy fuel mix across both developed and lessdeveloping economies. While developed economies are largely supporting the nonexhaustible energy sources for strengthening security of supply and mitigating climate change impacts through reduced greenhouse gases (GHGs) emissions (see Moselle, 2011); renewable energy sources provide favourable option for intensifying rural electrification and improve electricity access in less-developing economies where electricity infrastructure remains mostly centralised (Munasinghe, 1990; Pereira, et al. 2010).

However, more than 1.4 billion populations around the world still do not have access to modern energy services while only $31 \%$ of the population in Sub-Saharan Africa has access to electricity. One of the major reasons behind a vapid progress in the rural electrification process is due to the higher costs of grid extensions leading to budgetary constraints in dispersed rural areas with low load and population densities (Haanyika, 2006; Bhandari and Stadler, 2011). Many low-income household groups cannot afford to pay the upfront connections fees while the private sector lack appropriate incentives to render service to the less profitable (or rather unprofitable) and low-usage customers even though they may be willing and able to pay commercial prices for their electricity usage. Renewable technology offer suitable opportunity to electrify rural areas as the technology is capable of making better use of locally available resources, such as sunlight, biomass, wind and hydro power (Miller and Hope, 2000). However, developing decentralised electricity systems from renewable energy sources can be highly costly for poor rural population to afford in the absence of any access to credit while any possibilities of cost reductions from economies of scale vanishes due to small-scale of the plants.

Renewable energy which comes from different sources (primarily hydro, photovoltaic, wind, geothermal, tidal, waste to energy, etc.) has a common characteristic of having large sunk

\footnotetext{
${ }^{1} \mathrm{~A}$ backstop technology is a new technology producing a close substitute to an exhaustible resource by using relatively abundant production inputs and rendering the reserves of the exhaustible resources obsolete when the average cost of production of close substitutes falls below the spot price of exhaustible resources (Dasgupta and Heal, 1973).
} 
costs and almost negligible variable cost. Waste-to-energy (WtE) technologies, in particular, have negative fuel cost as plants usually receive some gates fees (at least in the UK) for accepting delivery of waste while waste is usually free (Jamasb and Nepal, 2010). These technologies require significant capital expenditure before producing any energy with no added fuel cost unlike other conventional fossil based technologies which incurs significant fuel costs. The average costs of renewable technologies are very much dependent on the output levels or scale with marginal cost being very low. The high upfront capital cost requirement for renewable technologies raises the levelised cost of electricity (lcoe) which is the constant price at which electricity is sold for the facility to breakeven over its lifetime as compared to other fossil fuelled power stations. Therefore, the increased deployment of renewable sources as a means to improve the electricity access rate in less developing economies largely hinges upon their ability to identify innovative mechanisms to attract both domestic and foreign capital and increase financing.

Less-developing countries are also not able to invest in energy research and development (R\&D), in particular, due to resource constraints. In 1994 the average R\&D expenditure as a percentage share of their GDPs was about $0.65 \%$ in developing countries and 3\% in industrialized countries (Pereira et al., 2010). Investing in renewable R\&D can bring the renewables 'down the cost curve' as there exists significant potential for future cost reductions due to learning (Moselle, 2011). However, developing economies have no culture of $R \& D$, in particular energy $R \& D$. $R \& D$ efforts in developing countries are primarily adaptive from technologies developed in advanced economies. Hence, the benefits from increased use of renewable technologies in less developed countries can critically depend on the technology and knowledge transfer (and the transfer rate) from advanced economies. Further, innovation diffusion only works better with policies that equally integrate the associated supply and demand-side factors (Brown, 1981; Heertje, 1983; Miller, 1998; Miller and Hope, 2000). However, such policies are quite rare in less-developed countries primarily due to shortage in skills and knowledge (see Pollitt and Stern, 2010).

The purpose of this article is to assess the potentials and role of renewables in rural electrification in less-developing countries citing Nepal as an example. The paper is planned as follows. Section 2 is an overview on the current energy sector scenario in Nepal. This section discusses the existing renewable technology in the country. Section 3 analyses the demand and supply-side constraints impending the spread of the renewable technologies in Nepal and other less developed countries. Finally, section 4 concludes with relevant policy 
recommendations in the Nepalese context but holding general relevance to all lessdeveloping economies in the world.

\section{Energy Sector Scenario in Nepal}

Nepal is a landlocked country in South Asia and occupies an area of 147,181 square kilometres with around 28 million inhabitants. Around $82 \%$ of the total population live in rural areas and the rest $18 \%$ resides in urban areas. The rural dominance in the country imply mass poverty as $38 \%$ of the population have disposable income of $\$ 1.25$ a day and the average per capita income is $\$ 427$ (WDI, 2011). The country has no energy R\&D culture due to resource constraints. Hence the geography, economy and the population aspects in relation to the current energy status makes Nepal a unique case study to assess the roles and potentials of renewables in less-developing countries.

Three broad types of energy sources exist in Nepal: commercial, traditional and alternative energy (WECS, 2006). Commercial sources of energy include conventional fossil based, carbon intensive (coal and petroleum fuels) and electricity from large hydro plants that leave no footprint to the environment. Traditional energy sources include biomass contents like fuel wood, biogas, agricultural by-products and animal waste used for direct combustion. Alternative energy sources include all non-conventional forms of energy such as photovoltaic, micro-hydro, wind, biofuels, geothermal, etc. The total energy consumption of the country remains primarily driven by traditional sources. In the Fiscal year (FY) $2008 / 2009$, the traditional forms of energy consumption constituted $87 \%$ of total energy consumption while the remaining $13 \%$ was met through commercial and alternative energy sources (Gurung et al. 2011).

Nepal boasts snowy mountains (Himalayan range) in the North which acts as a perennial source for many free flowing rivers establishing the country second richest in water resources in the world after Brazil (Joshi and Khadka, 2009). The nation is capable of producing 40 GW of technically and economically viable commercial electricity from large hydro plants (EIA, 2010). However, the vertically integrated Nepal Electricity Authority (NEA) has just managed to develop only $0.72 \mathrm{GW}$ of generation capacity including that of the Independent Power Producers (IPPs). The country, being a net importer of electricity, imports 100-150 MW of electricity annually from India. The developments of large hydropower is rather slow than anticipated. Thus, Nepal serves as a unique case of being resource rich and policy poor in terms of hydro power generation considering its potentials (Nepal and Jamasb, 2011). 
Figure one below shows that the energy consumption pattern by source type in 2008/09 has marginally changed as compared to 1995/1996. While fuel-wood comprised $77 \%$ of traditional energy consumption in 2008/09 (Gurung et al. 2011); marginal increment in commercial and alternative energy usage is observed in more than a decade time period. The nation remains distinctly dependent on biomass to meet the energy demand while renewables having a negligible share in total energy consumption.

Fig. 1: Energy Consumption by source type in $1995 / 96$ and $2008 / 09$ respectively (\% of total energy consumption)

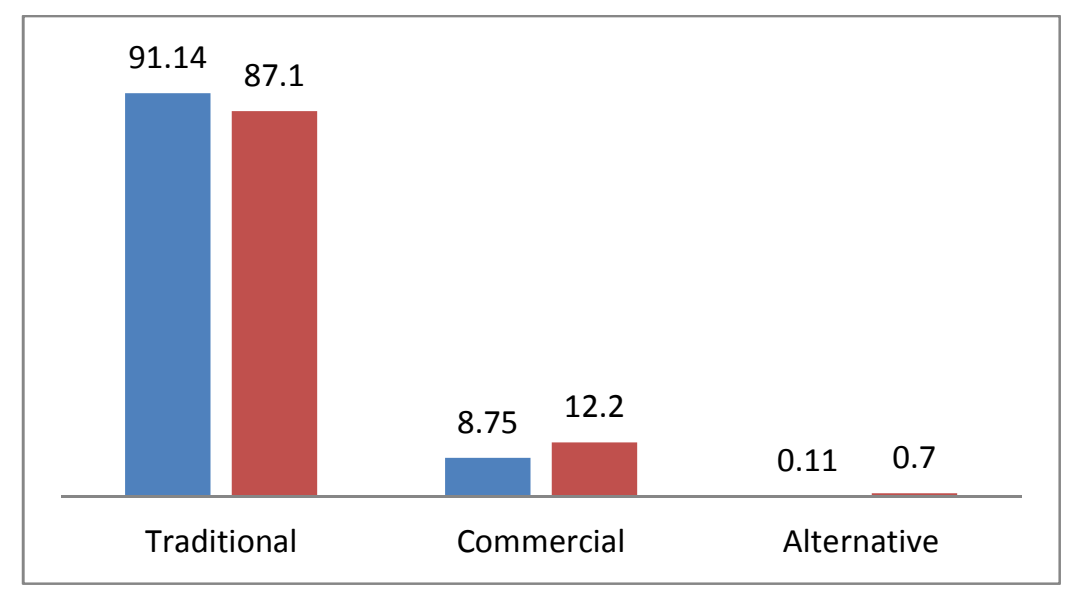

Energy consumption of traditional sources is driven by the residential sector unlike in most developed countries where the industrial sector drives the national energy consumption. In 2008/09, the residential sector in Nepal consumed $89 \%$ of energy contributing to major exploitation of forests and deforestation in rural areas (see Gurung et al. 2011). The transport sector consumed $5.2 \%$ of total energy (see fig. 2) which primarily includes the fossil based petroleum products. However, the lack of any oil, gas and coal reserves in the country implies that India remains the sole supplier of commercial energy sources to Nepal (WECS, 2006). Thus, a major share of export earnings is spent to import petroleum products annually and widening the bilateral trade deficit with India. Further, the irregularity in supply coupled with the rising and volatile prices of oil and gas in the international markets increases the risks of over-dependence on the imported commercial energy sources. 
Fig. 2: Sectoral decomposition of energy consumption (\% of total energy consumption)

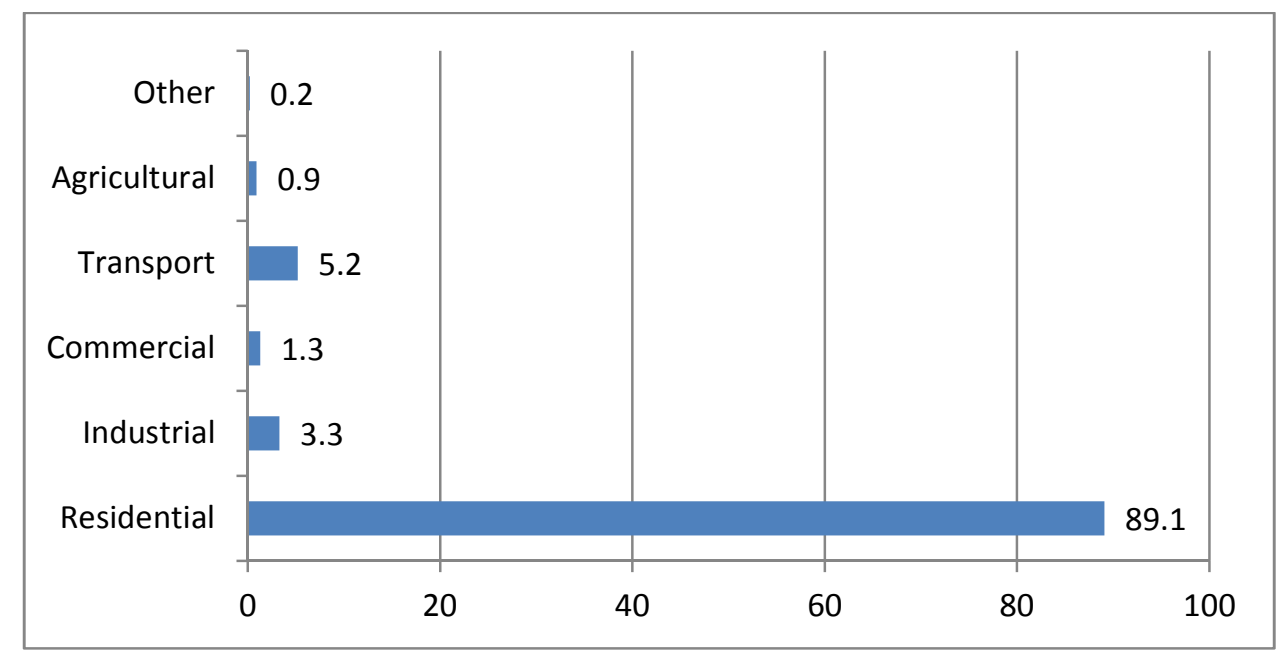

Reliable energy supply is necessary for stimulating an export-led economic growth in Nepal as in other less-developing countries (Dhungel, 2008). However, the 16 hours daily power cut in the nation during the winter of 2008/09 (see NEA, 2009) indicates that energy supply remains vulnerable and hampering Nepal's economic and social development. In 2010 alone, 678 GWh of energy demand was managed by load shedding (NEA, 2011). The inadequate power supply in Nepal has become a critical issue as rapid poorly-managed urbanisation and increased growth in energy intensive industries is set to increase the national energy requirement to $9563 \mathrm{GWh}$ by 2010 from the $4368 \mathrm{GWh}$ in 2010 (NEA, 2011). Technical losses are about $25 \%$ of power production while non-technical energy losses are also high in most South Asian countries including Nepal (Smith, 2003).

Around 16.5 million people currently living in Nepal are devoid of electricity and the country has an overall low score of 0.107 in terms of Human Development Index (HDI). Although. The rate of electrification increased to $43.6 \%$ in 2008 as compared to $30 \%$ in 2005 ; the benefits of electrification are largely confined to urban areas (IEA, 2008). Only 34\% of rural population had access to electricity in 2008 as compared to $90 \%$ access for urban population during the same year. Moreover, the urban population is growing at $18 \%$ while the rural population growth rate stands at around $1.2 \%$. The inability to develop large hydro-power as anticipated, increasing energy demand, constant power shortages, high technical and nontechnical network losses, mass energy poverty, energy dependence and the need to improve electricity access by affordable means are the acute concerns currently evolving the Nepalese 
energy sector. Alternative energy sources based on decentralized production can play a significant role in mitigating these concerns and contribute towards sustainable development of the nation.

The subsections below discuss the current status of the existing and potential renewable technologies in Nepal.

\subsection{Small hydro plants}

The presence of more than 6000 rivers (approximately 2800 miles in total length) combined with the distinct topography and unique sloppy hills provide many opportunities for small scale hydro power installation in Nepal. Small hydro facilities are classified under three categories depending upon the scale of the plants: mini hydro plants producing up to $1 \mathrm{MW}$ of power, micro hydro $(\mathrm{MH})$ producing up to $100 \mathrm{KW}$ of energy while pico-hydro plants producing up to $5 \mathrm{KW}$ of power. $\mathrm{MH}$ plants remain the most favoured option in Nepal with the first modern facility installed four decades ago followed by many other installations in the country.

The technology is popular as micro hydro plants can provide energy for rural residential lightening as well as for industrial processes like grinding milling in rural areas. Despite the feasibility and potentials of micro hydro plants in mass electrification; the progress has been rather slow due to affordability issues. The technology still remains costly in terms of sunk costs although the potential for future average cost reductions can be expected as the plant size grows due to economies of scale. The average cost of per KW in Nepal increased from US\$ 1000 in the early 1980s to above US\$ 2000 in the late 1990s (Rijal, 2000). A study by Mainali and Silveria (2010) estimated the average cost per KW to have risen to US\$ 2500 attributing the increasing costs to factor such as the increase in the economic scale of renewable energy business in recent years; increase in fixed subsidy amount per KW with the introduction of the renewable subsidy policy in 2000 and the maximum project cost ceiling enforced by the government as an eligibility criteria for subsidy approval. The costs is even higher for decentralized and remote Indian micro hydro projects in the range of US\$2670 to US\$ 5010 in the early 2000 with differences in factors such as the size of the project, and quality, origin of the equipment and other market factors (Nouni et al. 2009).

The average MH installation cost is US\$ 264 per household in Nepal (Mainali and Silviera 2010). Figure 3 provides a breakdown of the average cost structure per household in the 
Nepalese context. The contribution from government subsidy amounted to $\$ 144$ while local community contribution was $\$ 84$. Loans from external sources contributed $\$ 24$ and loan from local government sources (such as village development committee) contributed $\$ 4$ towards the average household cost of $\mathrm{MH}$ installation. The significant share of community contribution indicates a high potential for sustainability of $\mathrm{MH}$ technology towards rural electrification through popular community support in less developing countries like Nepal.

Fig. 3: Financial Mix by source

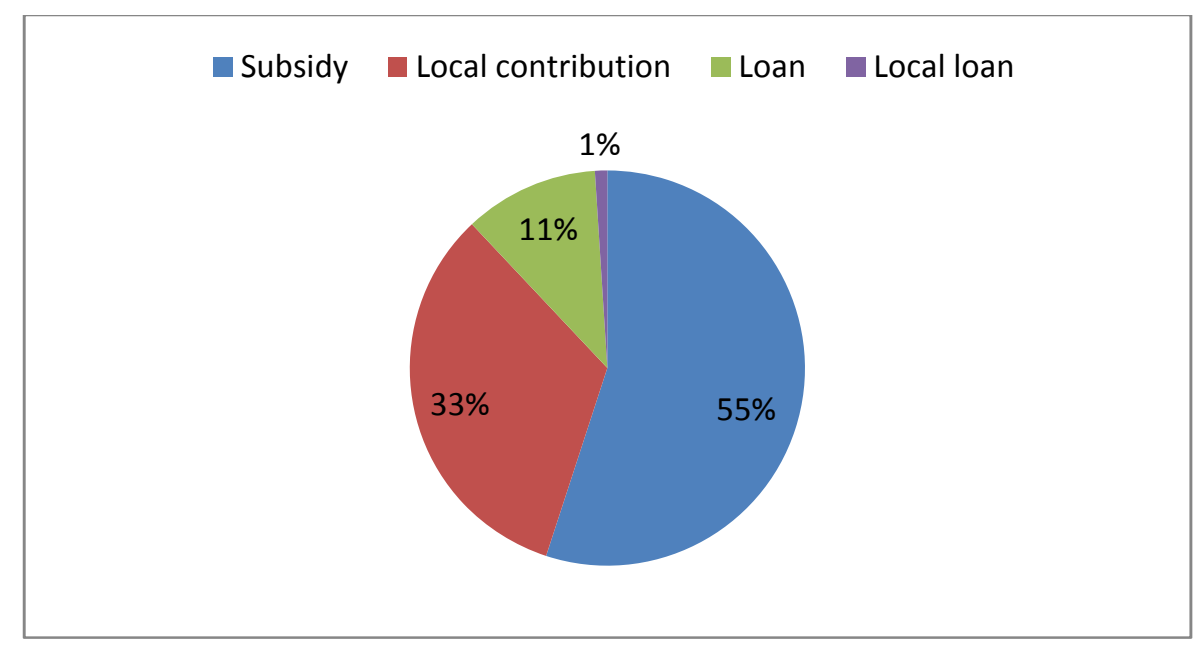

Source: Mainali and Silveira (2010)

\subsection{Solar Photovoltaic (PV)}

Solar Photovoltaic is another high-profile renewable energy technology used across the country. The presence of abundant and evenly distributed sunlight imply more than 300 sunny days in a year with an average solar radiation of $3.6-6.2 \mathrm{kWh} / \mathrm{m} 2 /$ day. Solar PV provides a viable option to meet electric energy demand in non-electrified rural areas in Nepal as well as meeting the growing urban demand for energy. The technology has never looked back since the installation of the first PV module in 1963 in the Bhadrapur Airport for navigational purpose (AEPC, 2003).

According to AEPC (2008), the solar PV systems in Nepal can be categorized under four broad types based on their application areas: a) solar home system (SHS) which is defined as the household electricity supply system with solar PV panel capacity of at least 10 Watts (W), battery, charge controller, and appropriate number of DC lights; b) small solar home system (SHSH) which have module size between $2.5 \mathrm{~W}$ and $10 \mathrm{~W}$, battery charge controlling mechanism and white light emitting diodes; c) community solar PV systems (CSHS) which 
includes solar PV powered water pumping system and d) institutional solar PV systems (ISPS) which includes the application of PV in public institutions such as schools, health clinics, religious buildings, etc. SHS remains the most popular solar PV technology in Nepal with a total number of about 115,000 installations (see Bhandari and Stadler, 2011). As such, the residential sector has been the driving force behind the increasing adoption of PV technology in the country.

The average costs of installation of SHS in Nepal ranges from US\$244 to US\$ 880 depending upon the size of the system although the costs can be sensitive towards factors like inflation and devaluation of the national currency (AEPC, 2003). Although the prices of SHS components are marginally falling in the international market; the price has remained fairly stable in Nepal due to economies of scale and competition in the market (Rai, 2004). Loans were used to cover $55 \%$ of costs, followed by $27 \%$ subsidy and the remaining $18 \%$ was financed from owners' equity (Mainali and Silviera, 2010).

\subsection{Wind Power}

Wind power is one of the most widely used renewable energy source around the globe, and one of the closest to being competitive with coal in terms of cost (Heal, 2009). However, the utilization of wind to generate power is negligible in Nepal given the considerable potential. The theoretical potential of wind power in Nepal is estimated to be $448 \mathrm{MW}$. The potential sites for wind power systems include the Mustang district. The nation being landlocked also eliminate the possibility to generate energy from offshore wind; a source much powerful but comparatively costly than onshore wind.

Figure 4 below shows the levelised private costs of renewable energy technologies against low carbon fossil sources in 2030 assuming a discount factor of $10 \%$ under high cost and low cost scenarios. Onshore wind is expected to compete with cleaned coal (i.e. carbon captured and stored (CCS)) in the future followed by offshore wind. However, it faces two difficulties in competing with other low carbon energy sources: a) intermittency as the wind does not blow all the time and b) locational issues as many sites with strong winds could be far requiring significant investment in grid capacity expansion. Such factors can raise the levelised cost of wind electricity. However, the effect of intermittency can be negligible if wind power is used to meet a low proportion of demand as in the Nepalese context. 
Fig. 4: Estimated 2030 levelised private cost (p/kwh) with a discount factor of $10 \%$

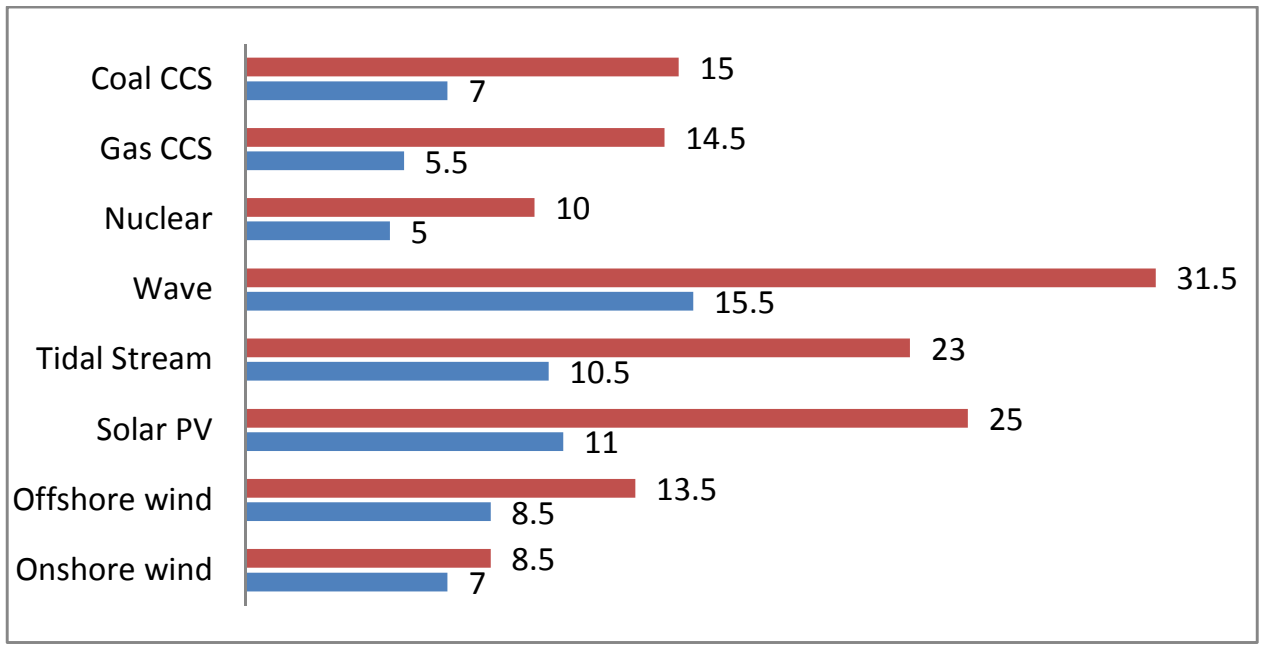

Source: Moselle, 2011

\subsection{Geothermal}

The utilization of geothermal energy in electricity production is rather unheard in the country though 32 hot water spring sites with temperatures exceeding 50 degree Celsius had been identified in the country after 2004. Geothermal energy provides roughly $2.1 \mathrm{MW}$ of energy with further development and investigation of the resource on-going. The extraction of geothermal energy is also capital intensive with no fuel costs but produces no emissions of any sort.

However, the cost assessment of renewable technology can be a difficult process given that the average cost of renewable technologies varies greatly on scale with low marginal cost. Most cost comparisons across energy technologies are based on levelised private costs as in figure 4. Form a policy making perspective, it is desirable that the costs comparison be based upon levelised social costs of electricity (see Heal, 2009). The levelised cost of electricity includes the negative externalities (external costs) such as the costs of greenhouse gas emitted. While levelised social costs provide a level playing field for costs comparison; a potentially complicating factor would be the right price of carbon which tends to vary across studies (see Stern 2006; Hope and Newberry, 2007; Strand, 2008; Nordhaus, 2009).

Table 1 shows the potentials for future cost reductions of selected renewable technologies based on experience (so called learning rates) and research and development. In case of solar thermal power, wind-offshore and small hydro; a large proportion of cost reductions can 
come from the learning and economies of scale associated with large-scale global deployment. The sooner less-developed countries get on with the job of a large-scale roll out of these renewable energy sources, the faster these economies can benefit from the improved economics of these technologies. However, less developed countries like Nepal cannot afford to spend on R\&D. In 2010, the group of 20 industrialised countries (popularly termed as G20) was responsible for $90 \%$ of investment in renewable technologies while the rest of the world only invested 10\% in clean energy technology (Pew, 2011). Thus, less developed countries have to rely on the technology transfer from advanced economies.

Table 1: Learning curves for selected energy technology

\begin{tabular}{|l|c|c|}
\hline Technology & Learning rate ignoring R\&D & Learning rate controlling for R\&D \\
\hline Small Hydro & $2.8 \%$ & $0.5 \%$ \\
\hline Waste to Electricity (WtE) & $57.9 \%$ & $41.5 \%$ \\
\hline Wind-onshore & $15.7 \%$ & $13.1 \%$ \\
\hline Solar thermal power & $22.5 \%$ & $2.2 \%$ \\
\hline Wind-offshore & $8.3 \%$ & $1.0 \%$ \\
\hline
\end{tabular}

Source: Jamasb and Kohler, 2007

Thus, Nepal like many other less developed economies exhibits a high potential for renewable energy sources which should encourage the use of renewable technologies. However, the empirical evidence suggests that the use of renewable technology is slower than anticipated while the high potential remains to be utilized. The next section recommends several demand and supply-side constraints to be overcome for facilitating a rapid the usage of renewable technology in Nepal.

\section{Addressing the Demand and Supply-Side Constraints}

Technology diffusion becomes effective with policies aimed at addressing both the demand and supply factors associated. Sociological traditions leading to uncertainty and high risks perception attached with new innovation is an important demand side aspect of technology diffusion in less developed countries (Agrawal, 1983; Rogers, 1995). Likewise, access to financial resources and credit can be critical factors to adopt any capital intensive technologies in rural areas in less developed countries (Roy, 1994). Lack of adequate supply (Griliches, 1957) and lack of proper market infrastructure are major supply-side deterrents for widespread adoption of technology (Foley, 1995). 
The theory of 'access gap' can further offer some guidance in the wider diffusion of renewable technology in developing countries. The 'access gap' refers to people and location which are beyond the reach of the market due to several supply-side aspects like unfair distribution or demand-side aspects like low disposable incomes. As such, equally important are the institutional, financial, technical and managerial barriers in promoting the alternative energy technologies in less developed economies like Nepal (Pokharel, 2003). However, several key issues needs to be imminently addressed so as to increase the spread the renewable energy technology in less developed countries like Nepal.

\subsection{Designing cautious subsidies and tax incentives}

The International Energy Agency (IEA) has defined energy subsidies as government support aimed at lowering the cost of energy usage through incentives to generate or via price reductions to consumers (IEA, 1999). Hence, energy subsidy is essentially a fiscal tool to close the gap between the cost of renewable energy and the affordability of low-income households. Extending electricity access through renewable technology from well-designed subsidy and tax mechanism across the poor should maximise the social welfare in less developed economies justifying its implementation. Hence, subsidy is an integral source to fund renewable technology in less developed countries like Nepal (see figure 3).

Subsidies for MH and SHS installations were introduced in 1981/1982 and 1996/1997 respectively in Nepal. The initial subsidy design was initially based on the percentage of equipment costs which led to undesired manipulation due to costs window-dressing. The subsidy policy was thus revised and redefined in 2000 based on per $\mathrm{kW}$ (NRs. 70,000 or US\$ 1030 per $\mathrm{kW}$ ) generated capacity (i.e. capacity payments) to monitor the quality and estimate actual power output of the MH projects. In 2006, a new inclusive policy to enhance the electricity access for the rural poor was mooted. The policy provides additional transportation subsidy depending upon the site remoteness in relation to the nearest road head (GON, 2006). Although a policy revision allowed the subsidies to reduce by $10 \%$ each year; the implementation was not possible due to political movies and vested interests (HMG, 2000). The Nepalese subsidy scheme for solar PV is also quite attractive when compared against direct subsidies provided in other growing economies like China, Sri Lanka and Indonesia (Martinot et al., 2001). As a step further, the government can also experiment with a consumption based subsidies together with the existing investment based subsidies to encourage the consumption of energy from renewable sources. Experiences from the US and 
Europe (in particular Germany and UK) demonstrates that feed-in tariffs (FIT) (i.e. paying consumers for the green energy they generate) can be an attractive cash-back mechanism for local and national governments to spur development of renewable energy (PEW, 2011).

Similarly, tax exemption/reduction schemes are also existent in Nepal as a means to bring down the sunk costs of renewables and likewise attract more investments. Commodity import duties and value added tax (VAT) are waived for green energy products like solar panels and hydro turbines in Nepal learning from countries like India, China and Indonesia (Liming, 2009).

However, the existing subsidy policy in the country has not worked to the satisfaction of everyone especially due to its cumbersome delivery process (Mainali and Silviera, 2010). The energy sector in Nepal being completely state-owned often experiences lengthy bureaucratic delays and lacks adequate transparency. While political volatility in the country could be a factor (see Nepal and Jamasb, 2011); the decision making also process becomes clumsy under a centralized decision making structure. The importance and sensitivity of electrification issues in less developed countries implies that the subsidies and tax policies should address the 'economic efficiency' and 'social equity' aspects of renewable electrification. While social equity can be the immediate priority; economic efficiency in the long-run would ensure sustainability of the sector. This will require a time-responsive design and monitoring of the existing subsidies and tax schemes.

\subsection{Improving access to (rural) credit}

Renewable energy technologies being highly capital intensive but having no running cost implies that a renewable plant with 30 years lifetime is prepaid for the next 30 years of electricity it produces. Hence, long-term debt financing seem justifiable in reducing the access gap. Start-up companies, in particular, lack sufficient capital for investment making the role of a loan more critical and attractive.

In Nepal, the Agricultural development Bank and the National Commercial Bank and have actively mobilized their capital on renewable energy sector out of the 109 banks that currently exist. These two state-owned banks accounted for $37 \%$ of renewable loans and $98 \%$ of the loans in micro hydro, solar PV and biogas in 2008 (Mainali and Silviera, 2010). While lack of adequate bank participation in the renewable sector is a concern; low-interest loans have often been misused and resulting in bad debts. This risks associated with bad debts can 
be detrimental in luring the financial institutions in green business. However, such risks and practice can be safeguarded against with adequate monitoring which may require setting up an appropriate institutional body. This will increase more banks participation allowing for new entries.

The Nepalese and Indian experiences suggest that excessive paperwork, lengthy bureaucratic procedures and stringent security requirements can be major obstacles for rural entrepreneurs in obtaining loans for renewable business (Miller and Hope, 2000). Eliminating such inefficiencies in decision making is essential so that the process becomes fast-tracked. International long term loans from foreign financial institutions such as the World Bank is also equally important in less developed countries as a means to increase investment in renewable sources. However, it may require stronger arrangements towards corruption control as the country lacks adequate transparency. Low interest and well monitored loans can help in develop the market infrastructure of renewables while also provide entrepenual incentives to cash-strapped individual to invest in renewable energy.

Easy access to credit facilities can increase the adoption of renewable technologies in less developed economies like Nepal while the role of credit is crucial in minimizing the financial gap and increase affordability of green technologies.

\subsection{Encouraging the Private Sector}

The private sector being 'profit maximizers' are generally reluctant to invest in renewable energy and aid the rural electrification process as extending electricity service to the poor is unprofitable and unattractive. However, elimination of all local taxes on PV modules and complete systems coupled with eliminating import duties can increase the unit gross margins. The Indian and Indonesian experience clearly suggest that changes in tax schemes on PV modules strongly affected the rate at which start-up private enterprise expanded their sales (Miller and Hope, 2000). Besides, the entry of new private players can be facilitated by creating a level playing field for both the state-owned companies and the private enterprises.

A supply-side grant per system sold as in Indonesia can be beneficial in luring the private sector and rapidly develop the market infrastructure in SHS. The experience from Bhutan suggests that public-private partnership is crucial for the development of small hydro technologies. Thus, encouraging private sector into the business is necessary to increase 
investment and allow for a wider adoption of renewable technologies in less developed economies like Nepal.

\subsection{Proper institutional settings}

The choice and use of renewable energy is contingent upon existing policy and implementing agencies at the macro-level, supply companies, dealers and financing institutions at the mesolevel and local community and household economy at the micro- level (Reddy, et al. 2009).The contribution of local community as a shareholder in the overall financial mix of renewable technologies is significant in less developed economies like Nepal. Thus, active involvement of local community by allowing them to manage their own power supplies is essential in harnessing locally available resources. One key aspect would be to decentralise the decision making process and let the decisions be made collectively at the local government level. However, the lack of managerial experience and subsequent social problems may necessitate a strong community mobilization and institutional capacity building at local levels.

Experiences from Bangladesh suggest that the local cooperatives can be a favourable delivery mechanism for the development of renewable energy in rural areas as socially-oriented cooperatives are more inclined to contribute towards improvement in local living conditions irrespective of profit margins (Yadoo and Cruickshank, 2010). Thus, more focus should be towards strengthening and encouraging socially oriented community-based organizations such as cooperatives to facilitate the use of dispersed renewable sources and contribute towards the electrification of rural areas in less developed economies.

\subsection{Extending adequate entrepreneurial support}

Developing countries lack sufficient skills and expertise often experiencing the severe stress of human resource constraints in governing the electricity sector (Pollitt and Stern, 2010). Thus, it is necessary that rural companies are provided with appropriate advisory and business support services apart from the technical support. Advising on issues such as end use of electricity, accounting procedures and micro financing are important factors influencing the use of distributed energy source in rural areas. The Indian experience indicates that the establishment of 'business advisory support services' for electrification purpose in India helped in developing the managerial competence among may rural start-up companies (IFC, 1998). The perceived human capital constraints among the less developed 
countries in the electricity sector constraints can be addressed through training exercise, awareness programmes, and research seminars to some extent.

\section{Conclusions}

This article analysed the roles and potentials of renewable energy sources in less-developed countries based on the Nepalese energy context. Less-developed countries like Nepal have significant potentials to produce electricity from locally available renewable energy sources. Harnessing energy from renewable sources can dramatically improve the electricity access in rural areas and reduce the over-dependence on traditional energy sources as well as foreign fuel imports. The larger adoption of renewable energy technology signals a technological shift from centralized energy production and transmission towards a decentralized structure. The switch towards a decentralized production structure implies no need to engage in costly grid expansion and avoid the network energy losses. It also indicates a shift in preferences towards small-scale facilities from large-scale traditional power plants in less developed economies although economies of scale sets in as plant size increases.

Addressing the demand and supply-side constraints is necessary for the wider promotion of renewable energy technologies in less-developed economies. Both domestic and international actors will play a major role in the large scale adoption of renewable technology in lessdeveloped countries. Domestic factors such as favourable government policies under a favourable policy environment, effective regulatory mechanisms, smart subsidies and tax incentives, indigenous innovation with required financial and institutional support can play a vital role in the widespread dissemination of renewable energy technology. The role of local community organizations such as cooperatives is crucial so adequate entrepreneurial and technical support is necessary. Similarly, increased investment in renewable energy sources from international sources in the form of well monitored long- term loans and grants coupled with timely technology transfer are essential to extend electricity services among rural-based communities in less-developed economies. 


\section{References:}

AEPC (2003). Price Analysis of Solar Home System: Assessment of Influences of Subsidy, Alternative Energy Promotion Center, Government of Nepal, 2003.

AEPC (2008). Status of Solar Photovoltaic Sector in Nepal in 2006, Alternative Energy Promotion Center, Government of Nepal, 2008.

Agrawal, B.(1983). Diffusion of Rural Innovations: some analytical issues and the case of wood-burning stoves, World Development, Vol.11 (4), pp. 359-376.

Brown, L. (1981). Innovation Diffusion, Methuen, New York.

Bhandari, R. and Stadler, I. (2011). Electrification Using Solar Photovoltaic Systems in Nepal, Applied Energy, Vol. 88, pp. 458-465.

Dasgupta, P. and Heal, G. (1973). The Optimal Depletion of Exhaustible Resources, Review of Economic Studies- Special Issue on Economics of Exhaustible Resources, pp. 3-28.

Dhungel, R. K. (2008). A Causal Relationship between Energy Consumption and Economic Growth in Nepal, Asia-Pacific Development Journal, Vol. 15(1), pp. 137-150.

EIA (2010). Energy Information Administration, Washington, DC, United States.

Foley, G. (1995). Photovoltaic Applications in rural Areas of Developing World, World Bank, Washington DC, USA.

GON (2006). Rural Energy Subsidy Policy, Government of Nepal, 2006.

Grilliches, Z. (1957). Hybrid Corn: An Exploration in the Economics of Technical Change, Econometrica, Vol. 25(4), pp.501-522.

Gurung, A; Bryesecon, I and Oh, S.E (2011). Micro hydropower: A Promising Decentralized Renewable Technology and Its Impact on rural Livelihoods, Scientific Research and Essays, Vol. 6 (6), pp.1240-1248. 
Haanyika, C.M. (2006). Rural Electrification Policy and Institutional Linkages, Energy Policy, Vol. 34, pp. 2977-2993.

Heal, G. (2010). Reflections-The Economics of Renewable Energy in the United States, Review of Environmental Economics and Policy, Vol. 4, Issue 1, pp. 139-154.

Heertje, A. (1983). Can we explain Technical Change? In: Macdonald et al., (Eds), The Trouble with Technology; Explorations in the Process of Technical Change. Frances Printer, London.

Hotelling, H. (1931). The Economics of Exhaustible Resources, Journal of Political Economy, pp. 137-175.

Hope, C. and Newberry, D.M.(2007). Calculating the Social Costs of Carbon, Cambridge Working Papers in Economics 0749, Faculty of Economics, University of Cambridge, UK.

HMG (2000). Subsidy for Renewable Energy, His Majesty's Government of Nepal, 2000.

IEA (1999). International Energy Agency, World Energy Outlook, OECD, Paris.

IEA (2008). The World Energy Outlook, Electricity Access Database, International Energy Agency, Paris, France.

IFC (1998). The Evolution of Solar Development Corporation Concept in Relation to World Bank Group/ GEF Financing of Solar Photovoltaic Technology and Related Experiences, IFC Environment Division, Washington, DC.

Jamasb, T. and Kohler, J. (2007). Learning Curves for Energy Technology and Policy Analysis-A Critical Assessment, Cambridge Working Papers in Economics 0752, Faculty of Economics, University of Cambridge, UK.

Jamasb, T. and Nepal, R. (2010). Issues and Options in Waste Management: A Social CostBenefit Analysis of Waste-to Energy in the UK, Resources, Conservation and Recycling, Vol. 54(12), pp.1341-1352.

Joshi, N. N and Khadka, S. R. (2009). Nepal: Crises, Challenges and Perspectives, Social Watch, Kathmandu, Nepal. 
Liming, H.(2009). Financing Rural Renewable Energy: a comparison between India and China, Renewable and Sustainable Energy Reviews, Vo. 13, pp. 1096-1103.

Mainali, B. and Silviera, S. (2010). Financing Off-Grid Rural Electrification: Country Case Nepal, Vol. 34 (4), Energy, pp. 1-8.

Martinot, E; Cabraal, A and Mathur, S. (2001). World Bank/GEF Solar Home system Projects: Experiences and Lessons Learned 1993-2000. Renewable and sustainable Energy Reviews, Vol. 5, pp. 39-57.

Miller, D. (1998). Agents of Sustainable Technological Change; the case of Solar Electrification in the Developing World. Ph.D. Thesis. Cambridge University.

Miller, D. and Hope, C. (2000). Learning to Lend for Off-Grid Solar Power: Policy Lessons from World Bank loans to India, Indonesia, and Sri Lanka, Energy Policy, Vol. 28, pp. 87105.

Munasinghe, M. (1990). Rural Electrification in the Third World, Power Engineering Journal, July, pp. 189-202.

Moselle, B. (2011). Why Support Renewables? EPRG Spring Research Seminar, University of Cambridge, May 13, 2011.

NEA (2011). Annual Report 2009-2010, Nepal Electricity Authority, Kathmandu, Nepal.

Nepal, R. and Jamasb, T. (2011). Reforming Small Power Systems under Political Volatility: The Case of Nepal, Cambridge Working Papers in Economics 1133, Faculty of Economics, University of Cambridge, UK.

Nordhaus, W. (2009). A question of balance: Weighing the Options on Global Warming, Yale University Press.

Nouni, MR; Mullick, SC and Kandpal; TC (2006). Techno-Economic of Micro Hydro Projects for Decentralized Power Supply in India, Energy Policy, Vol.34 (10), pp.1161-1174. 
Pereira, M.G; Freitas, M.A.V and Silva, N.F. (2010).Rural Electrification and Energy Poverty: Empirical Evidences from Brazil, Renewable and Sustainable Energy Reviews, Vol. 14, pp. 1229-1240.

Pew (2011). Who is winning the Clean Energy Race? The Pew Charitable Trusts, 2011.

Pokharel, S. (2003). Promotional Issues on Alternative Energy Issues in Nepal, Energy Policy, Vol.31, pp. 307-318.

Pollitt, M. and Stern, J. (2010). Human Resource Constraints for Electricity regulation in Developing Countries: Developments Since 2001, Utilities Policy, Vol. 19 (2), pp. 53-60.

Rai, S. (2004). Sustainable Dissemination of Solar Home Systems for Rural Development Experiences in Nepal, Energy Sustainable Development, VIII (2), pp.47-50.

Reddy, B.S. and Srinivas, T. (2009). Energy Use in Indian Household Sector - an actor oriented approach, Energy, Vol. 34, pp. 992-1002.

Rijal, K. (2000). Mini-and micro-hydropower development: Stats, issues and strategies for the Hindu Kush Himalayan Region, NESS Journal of Engineering, Vol. 9, pp. 86-92.

Rogers, E.(1995). Diffusion of Innovations, $4^{\text {th }}$ Edition, The Free Press, New York.

Roy, K.(1994). Neglected Issues in Technical change and Rural Development: An Overview. In: Roy, K; Clark, C. (Eds.), Technological Change and Rural Development in Poor Countries. Oxford University Press, Calcutta.

Smith, T. B. (2004). Electricity theft: A Comparative Analysis, Energy Policy, Vol. 32, pp.2067-2076.

Stern, N. (2006). The Economics of Climate Change: The Stern Review, London, Her Majesty's Treasury.

Strand, J.(2008). Energy Efficiency and Renewable Energy Supply for the G-7 countries, with emphasis on Germany, IMF Working Papers, pp.1-35.

WDI (2011). World Development Indicators, The World Bank, Washington DC, 2011.

WECS, (2006). Energy Synopsis Report-Nepal, Water and Energy Commission secretariat, Government of Nepal, Kathmandu, 2006. 
Yadoo, A. and Cruickshank, H. (2010). The Value of Cooperatives in Rural Electrification, Energy Policy, Vol. 38, pp. 2941-2947. 